\title{
Potensi tanaman padi yang dipupuk dengan kompos Chromolaena odorata; penghasil gabah dan sumber hijauan pakan ternak penunjang ketahanan pangan
}

\section{Potential of rice crop fertilized with compost of Chromolaena odorata to produce grain yield and forage sources supporting food security}

\author{
JAMILAH ${ }^{1, \vartheta}$, JUNARTI $^{2}$, SRI MULYANI ${ }^{1}$ \\ ${ }^{1}$ Universitas Tamansiswa Padang. Jl. Tamansiswa No. 9 Padang, Sumatera Barat. \\ ${ }^{2}$ Universitas Andalas, Jurusan Ilmu Tanah, Fakultas Pertanian, Kampus Limau Manis. Jl. Limau Manis, Kecamatan Pauh, Padang, Sumatera Barat. \\ "email: mil_munir@yahoo.com
}

Manuskrip diterima: 10 April 2016. Revisi disetujui: 1 Agustus 2016

\begin{abstract}
Abstrak.
Abstrak. Jamilah, Junarti, Mulyani S. 2016. Potensi tanaman padi yang dipupuk dengan kompos Chromolaena odorata; penghasil gabah dan sumber hijauan pakan ternak penunjang ketahanan pangan. Pros Sem Nas Masy Biodiv Indon 2: 27-31. Penelitian dilakukan di dua lokasi yaitu di lahan sawah Kecamatan Bayang, Kabupaten Pesissir Selatan dan Kecamatan Koto Tangah, Padang pada bulan Februari hingga Juli 2015. Penelitian disusun dalam Rancangan Petak Terpisah (RPT) dalam Rancangan Lingkungan Acak Kelompok. Petak utama disusun berdasarkan tinggi pemangkasan yang terdiri atas 3 perlakuan yaitu: (1) $P_{0}=$ tidak dipangkas, (2) $P_{1}=$ dipangkas pada ketinggian $5 \mathrm{~cm}$ di atas permukaan tanah (dpt), dan (3) $\mathrm{P}_{2}=$ dipangkas pada ketinggian $15 \mathrm{~cm}$ dpt. Anak petak merupakan perlakuan pemberian kompos $C$. odorata + pupuk buatan, terdiri atas 3 komposisi pupuk yaitu: (1) $\mathrm{F}_{1}=5 \mathrm{Mg} \mathrm{ha}^{-1} \mathrm{kompos}$. odorata + $100 \%$ takaran pupuk buatan rekomendasi (TPBR), (2) $\mathrm{F}_{2}=7,5 \mathrm{Mg} \mathrm{ha}^{-1}$ kompos $C$. odorata $+75 \% \mathrm{TPBR}$, dan (3) $\mathrm{F}_{3}=10 \mathrm{Mg}$ ha ${ }^{-1}$ kompos $C$. odorata $+50 \%$ TPBR, dikelompokkan menjadi 3 kelompok, sehingga terdapat 27 petak percobaan. Data dianalisis secara statistik menggunakan analysis of variance (ANOVA) pada taraf kepercayaan $\alpha=95 \%$. Parameter pengamatan meliputi berat hijauan pakan ternak, anakan produktif, umur berbunga, kadar $\mathrm{C} / \mathrm{N}$, kandungan protein kasar, panjang malai, dan berat gabah kering panen. Hasil penelitian menunjukkan bahwa hijauan pakan ternak tertinggi mencapai 7,17 $\mathrm{Mg} \mathrm{ha}^{-1}$ yang diperoleh dari perlakuan pemangkasan pada saat awal primordial bunga, pada ketinggian $15 \mathrm{~cm}$ dari permukaan tanah. Berat gabah kering giling tertinggi diperoleh pada tanaman yang tidak dipangkas mencapai $6,22 \mathrm{Mg} \mathrm{ha}^{-1}$, sedangkan pada tanaman yang dipangkas pada ketinggian $15 \mathrm{~cm}$ dari permukaan tanah mencapai $4,20 \mathrm{Mg} \mathrm{ha}^{-1}$. Secara umum, pemberian $5 \mathrm{Mg} \mathrm{ha}^{-1}$ pupuk kompos C. odorata $+100 \%$ takaran pupuk buatan rekomendasi merupakan komposisi pupuk yang paling tepat untuk menghasilkan gabah padi dan hijauan pakan ternak yang optimal
\end{abstract}

Kata kunci: Chromolaena odorata, hijauan pakan ternak, padi IR66, Pandan Wangi

Abstrak. Jamilah, Junarti, Mulyani S. 2016. Potential of rice crop fertilized with compost of Chromolaena odorata; to produce grain yield and forage sources supporting food security. Pros Sem Nas Masy Biodiv Indon 2: 27-31. The research had been done on two locations in Bayang, South Pesisir District wetland and Koto Tangah Disrict, Padang in February to July 2015. The research was arranged in a Split Plot Design (SPD) and random blocked design. Main plot was arranged based on the height of trimmed, consisted of 3 treatments, i.e. (1) $\mathrm{P}_{0}=$ not trimmed, (2) $\mathrm{P}_{1}=$ trimmed on $5 \mathrm{~cm}$ in height above on the ground (aog) and (3) $\mathrm{P}_{2}=$ trimmed on $15 \mathrm{~cm}$ in height $(\mathrm{aog})$. The subplots were a treatment of composting of $C$. odorata and artificial fertilizer, consisted of three fertilizers composition that were: (1) $\mathrm{F}_{1}=5 \mathrm{Mg} \mathrm{ha}^{-1}$ compost of $C$. odorata $+100 \%$ recommendation artificial fertilizer rate $(\mathrm{RAFR})$, (2) $\mathrm{F}_{2}=7.5$ $\mathrm{Mg} \mathrm{ha}^{-1}$ compost of $C$. odorata $+75 \%$ RAFR and (3) $\mathrm{F}_{3}=10 \mathrm{Mg} \mathrm{ha}^{-1}$ compost of $C$. odorata $+50 \%$ RAFR, blocked into three, therefore there were 27 treatment plots. Data were analyzed statistically by using Analysis of Variance (ANOVA) at 95\% confidence level. Parameter of observations included forage, productive tillers, date to flowering, $\mathrm{C} / \mathrm{N}$ ratio, crude protein component, panicle length and weight of dry grain harvest. The results showed that more weight of forage was obtained from the trimmed treatment at the beginning of early primordial at $15 \mathrm{~cm}$ aog reached $7.17 \mathrm{Mg} \mathrm{ha}^{-1}$ than others. More weight of dry milled grain on plants that were not trimmed reached $6.22 \mathrm{Mg} \mathrm{ha}^{-1}$ than others. Generally, the composting of $5 \mathrm{Mg} \mathrm{ha}^{-1}$ C. odorata $+100 \%$ RAFR was the most appropriate fertilizer composition to produce the rice grain and forage optimally. 
PROS SEM NAS MASY BIODIV INDON

Volume 2, Nomor 1, Agustus 2016

Halaman: 27-31

\section{PENDAHULUAN}

Produksi padi di Sumatera Barat tidak meningkat secara signifikan meskipun telah dilakukan upaya pengembangan teknik budi daya secara intensif hingga rekayasa pemupukan. Berdasarkan data Badan Pusat Statistik (2016), pada tahun 2015 hasil padi rerata mencapai 5,17 $\mathrm{Mg} \mathrm{ha}{ }^{-1}$ dengan rerata 10 tahun terakhir hanya $4,64 \mathrm{Mg}$ $\mathrm{ha}^{-1}$. Produksi padi yang tidak meningkat tersebut dinyatakan sebagai kondisi leveling-off, antara lain disebabkan oleh penurunan kualitas sumber daya lahan (soil sickness) yang berdampak terhadap penurunan produktivitas (BPTP Sulawesi Tengah 2009). Maksud pernyataan tersebut adalah sebanyak apapun input yang diberikan dalam budi daya, baik takaran pupuk, jenis pupuk, benih padi, maupun pestisida, produksi tanaman tidak dapat meningkat secara signifikan. Hal ini disebabkan produksi padi tidak mampu meningkat lagi melebihi sifat genetiknya meskipun input yang diberikan sudah tinggi. Berdasarkan hasil penelitian Kuspriyanto (2008), jenis dan dosis pupuk yang diberikan petani di Kecamatan Jatisrono, Jawa Tengah tidak berkolerasi nyata dengan produktivitas padi maupun kandungan $\mathrm{N}, \mathrm{P}$, dan $\mathrm{K}$ dalam tanah.

Salah satu upaya untuk mengatasi masalah tersebut adalah dengan melakukan pemangkasan tanaman padi pada fase vegetatif maksimum atau saat tanaman mencapai fase awal primordial bunga. Pada fase tersebut, kandungan gizi tanaman padi cukup tinggi karena semua energi disimpan sebagai bahan organik dan disiapkan untuk memasuki fase pertumbuhan generatif. Pemangkasan tanaman padi dilakukan seperti yang dilakukan pada rumput yang dijadikan sebagai pakan ternak. Keunggulan pemangkasan tanaman padi dibandingkan rumput yang sengaja dijadikan sebagai hijauan pakan ternak adalah tanaman padi diberi pupuk secara intensif dibandingkan tanaman rumpun, karena petani sangat mengharapkan hasil gabah padi yang tinggi. Pemberian pupuk yang optimal menyebabkan kualitas hijauan padi seperti kandungan protein kasar lebih tinggi dan kandungan serat kasar lebih rendah dibandingkan tanaman rumpun atau jerami padi yang dihasilkan saat panen. Akan tetapi, kelebihan pemberian pupuk yang tanpa disertai pemangkasan justru dapat merugikan tanaman padi, antara lain tanaman menjadi mudah terserang hama dan penyakit serta mudah rebah akibat tertiup angin maupun terpaan hujan.

Tanaman padi Cisokan yang dipangkas memiliki pertumbuhan vegetatif dua kali lipat dibandingkan dengan tanaman yang tidak dipangkas (Jamilah et al. 2015). Dengan pemangkasan, tanaman padi menunjukkan pemulihan dengan cepat, sehingga mendorong tanaman untuk menyerap hara dari tanah sebanyak-banyaknya dalam waktu singkat. Dengan demikian, tanaman padi yang dipangkas akan menyerap unsur hara lebih banyak dibandingkan tanaman yang tidak dipangkas. Hal ini menyebabkan pupuk yang diberikan tidak akan tersisa lebih banyak di dalam tanah. Perlakuan pemangkasan pada tanaman padi akan memberikan nilai tambah bagi petani karena selain petani mendapatkan hasil hijauan pakan ternak, juga mendapatkan gabah padi, sehingga model ini
ISSN: $2407-8050$

DOI: $10.13057 / \mathrm{psnmbi} / \mathrm{m} 020105$

memberikan keuntungan ganda bagi petani maupun peternak.

Ketinggian pemangkasan yang tepat pada tanaman padi perlu diketahui untuk dipanen hijauannya serta menghasilkan produksi padi yang maksimal. Dengan demikian, penelitian ini bertujuan untuk memperoleh hijauan pakan ternak yang dipangkas pada berbagai macam ketinggian dan hasil gabah padi yang diberi pupuk kompos C. odorata sebagai model integrasi padi dan sapi guna menunjang ketahanan pangan di Indonesia.

\section{BAHAN DAN METODE}

Penelitian dilakukan di dua lokasi lahan sawah yaitu di Sungai Lareh, Lubuk Minturu, Kota Padang dan Bayang Utara, Pesisir Selatan, Sumatera Barat. Penelitian ini dilakukan dari bulan Februari hingga Juli 2015. Penelitian ini merupakan bagian dari penelitian Stranas yang berjudul "Potensi Tanaman Padi Dipangkas secara Periodik untuk Pakan Ternak Pada Metode Budidaya Integrasi Padi Ternak untuk Menunjang Kedaulatan Pangan dan Daging”. Bahan yang digunakan antara lain benih padi IR66 berumur pendek dengan potensi hasil mencapai 5,5 $\mathrm{Mg} \mathrm{ha}{ }^{-1}$ (Suprihatno et al. 2009) dan Pandan Wangi, pupuk kompos $C$. odorata yang siap pakai yang dibuat dengan perbandingan $40 \%$ pupuk kandang $+60 \%$ C. odorata, dikomposkan selama 1 bulan, pupuk urea, SP-36, dan $\mathrm{KCl}$. Percobaan disusun dalam Rancangan Petak Terpisah (RPT) dalam Rancangan Lingkungan Acak Kelompok. Petak utama disusun berdasarkan tinggi pemangkasan yang terdiri atas 3 perlakuan yaitu: (1) $\mathrm{P}_{0}=$ tidak dipangkas, (2) $\mathrm{P}_{1}=$ dipangkas pada ketinggian $5 \mathrm{~cm}$ di atas permukaan tanah (dpt), dan (3) $\mathrm{P}_{2}=$ dipangkas pada ketinggian $15 \mathrm{~cm}$ dpt. Anak petak merupakan perlakuan pemberian kompos C. odorata + pupuk buatan, terdiri dari 3 komposisi pupuk yaitu: (1) $\mathrm{F}_{1}=5 \mathrm{Mg} \mathrm{ha}^{-1}$ kompos C. odorata $+100 \%$ takaran pupuk buatan rekomendasi (TPBR), (2) $\mathrm{F}_{2}=7,5$ $\mathrm{Mg} \mathrm{ha}^{-1}$ kompos $C$. odorata $+75 \%$ TPBR, dan (3) $\mathrm{F}_{3}=10$ $\mathrm{Mg} \mathrm{ha}^{-1}$ kompos $C$. odorata $+50 \%$ TPBR, dikelompokkan menjadi 3 kelompok, sehingga terdapat 27 petak percobaan. Data dianalisis secara statistika dengan analysis of variance (ANOVA) pada tingkat kepercayaan 95\%. Uji lanjut dilakukan dengan menggunakan analisis uji lanjut Beda Nyata Terkecil (BNT).

Lahan sawah dilumpurkan kemudian dibuat petak percobaan berukuran $2 \mathrm{~m}$ x $2 \mathrm{~m}$ dengan jarak penanaman $25 \mathrm{~cm}$ x $25 \mathrm{~cm}$. Benih padi disemai pada petak persemaian hingga berumur 2 minggu, kemudian dipindah ke lapang dengan 2 anakan per titik tanam. Pupuk buatan urea, SP-36, dan $\mathrm{KCl}$ diberikan sesuai perlakuan dengan takaran rekomendasi $100 \mathrm{~kg}$ urea $+50 \mathrm{~kg} \mathrm{ZA}+150 \mathrm{~kg} \mathrm{SP-36} \mathrm{dan}$ $100 \mathrm{~kg} \mathrm{KCl}$ pada umur 45 hst (hari setelah tanam), selanjutnya dilakukan pemangkasan. Parameter pengamatan meliputi berat hijauan pakan ternak, anakan produktif, umur berbunga, rasio karbon/nitrogen, kandungan protein kasar, panjang malai, umur berbunga, dan berat gabah kering panen. Penetapan rasio $\mathrm{C} / \mathrm{N}$ serta kandungan protein kasar dilakukan dengan menggunakan 
metoda Kjeldahl, sedangkan pengukuran kadar C-organik dilakukan dengan metode Walkley and Black.

\section{HASIL DAN PEMBAHASAN}

Hijauan pakan ternak yang dihasilkan dari perlakuan pemangkasan $5 \mathrm{~cm}$ dan $15 \mathrm{~cm}$ dari permukaan tanah (dpt) yang diberi berbagai komposisi pupuk kompos dan pupuk buatan disajikan pada Tabel 1. Rasio $\mathrm{C} / \mathrm{N}$ pada hijauan pakan ternak dari tanaman yang dipangkas pada awal primordial bunga cukup rendah dan hampir sama dengan rasio $\mathrm{C} / \mathrm{N}$ rumput gajah yang berkualitas yaitu sekitar 31,18 (Susanti 2007). Tanaman yang diberi pupuk kompos $C$. odorata yang tinggi menghasilkan rasio $\mathrm{C} / \mathrm{N}$ hijauan paling rendah, sebaliknya jika pemberian pupuk kompos diturunkan dan pupuk buatan dinaikkan maka rasio $\mathrm{C} \mathrm{N}$ meningkat dan berbanding lurus antara perlakuan pemupukan dengan rasio $\mathrm{C} / \mathrm{N}$ hijauan pakan ternak yang dihasilkan.

Secara umum, produksi hijauan pakan ternak dari tanaman padi sawah baik yang dipangkas $5 \mathrm{~cm}$ maupun 15 $\mathrm{cm}$ dpt tidak berbeda nyata. Hijauan pakan ternak yang dihasilkan cukup tinggi yaitu mencapai $7,17 \mathrm{Mg} \mathrm{ha}^{-1}$. Menurut Pringati Singa (2013) dan Dinas Peternakan Jawa Barat (2016), harga hijauan pakan ternak untuk berat setiap $25 \mathrm{~kg}$ adalah Rp10.000,00. Oleh sebab itu, hijauan pakan ternak merupakan hasil sampingan dari tanaman padi selain gabah. Akan tetapi, pada saat tanaman dipanen pada fase matang fisiologis, berat jerami paling rendah diperoleh pada perlakuan pemangkasan $5 \mathrm{~cm}$ dpt. Berat jerami tertinggi diperoleh pada tanaman yang tidak dipangkas. Hijauan pakan ternak yang dipangkas pada tanaman padi setinggi $5 \mathrm{~cm}$ dari permukaan tanah, menyebabkan menurunnya berat jerami. Hal ini disebabkan setiap pemangkasan yang dilakukan pada hijauan pakan ternak akan menghambat berkembangnya anakan yang tidak produktif, sehingga mengurangi bobot jerami padi. Menurut Martawidjaja (2003), jerami padi dapat digunakan sebagai pengganti rumput segar hanya sekitar $10 \%$ dari total pakan.

Dilihat dari data pada Tabel 1, diperoleh gambaran bahwa tanaman yang dipangkas saat awal primordial bunga, berat jerami yang dihasilkan berkurang sebanyak angka pangkasan hijauan segar awal primordial bunga tersebut. Berdasarkan hasil analisis kandungan protein kasar pada tanaman padi yang dipangkas saat awal primordial bunga rata-rata sebesar 9,83\%, sedangkan menurut laporan dari Jamilah et al. (2011), kandungan protein hijauan tersebut dapat mencapai $12 \%$.

Kandungan protein pada jerami yang tidak dipangkas saat awal primordial bunga sekitar 5\%, sedangkan kandungan protein pada jerami padi dari tanaman yang dipangkas saat awal primordial bunga sebesar $6,60 \%$. Kandungan protein yang menurun disebabkan sebagian protein yang ada pada bagian hijauan tanaman sudah ditranslokasikan ke bagian bunga dan buah. Menurut PNPM Agribisnis Perdesaan (2009) dan Sinar Tani (2013), kandungan protein kasar rumput gajah yang selalu dipotong selalu di atas 7\%, dan hal ini merupakan hijauan pakan yang berkualitas untuk ternak tanpa diberi perlakuan terlebih dahulu.

Berdasarkan hasil yang diperoleh, produksi hijauan pakan yang dipanen saat awal primordial bunga merupakan pengurang produksi jerami yang dihasilkan pada saat usia matang fisiologis (panen). Hal yang sama juga dilaporkan oleh Jamilah et al. (2015) bahwa pada tanaman padi jenis Cisokan, hijauan pakan yang dihasilkan mencapai 4,19 Mg $\mathrm{ha}^{-1}$, sedangkan sisa jerami yang dihasilkan saat panen mencapai $15,9 \mathrm{Mg} \mathrm{ha}^{-1}$. Jika tanaman tidak dipangkas maka jerami yang dihasilkan saat panen mencapai 18,79 $\mathrm{Mg} \mathrm{ha}{ }^{-1}$. Pertumbuhan tanaman yang menentukan hasil gabah kering panen antara lain jumlah anakan produktif dan panjang malai padi. Anakan produktif akan menurun jumlahnya jika dilakukan pemotongan hijauan pakan ternak atas setinggi $5 \mathrm{~cm}$ dari permukaan tanah. Akan tetapi, panjang malai pada tanaman yang tidak dipangkas lebih panjang dibandingkan tanaman yang dipangkas. Ketinggian pemangkasan tidak mempengaruhi panjang malai secara nyata (Tabel 2).

Pengaruh pemangkasan secara umum dapat memperlambat umur berbunga tanaman padi. Tanaman yang dipangkas pada ketinggian $5 \mathrm{~cm}$ dpt, umur berbunga lebih lambat 10 hari dibandingkan tanaman yang tidak dipangkas, sedangkan tanaman yang dipangkas $15 \mathrm{~cm} \mathrm{dpt}$ lebih lambat sekitar 6 hari dibandingkan dengan yang tidak dipangkas.Tindakan pemangkasan tersebut bertujuan agar tidak menimbulkan pengaruh yang besar terhadap kandungan karbohidrat pada batang sehingga harus tetap mempertahankan tinggi pemangkasan yang optimum. Dilihat dari jumlah anakan produktif yang dihasilkan menunjukkan bahwa terjadi penurunan jumlah anakan produktif pada tanaman yang dipangkas pada ketinggian 5 cm dpt. Hal ini disebabkan karena banyak sumber cadangan makanan dan energi yang sudah terangkut ketika dilakukan pemangkasan. Oleh sebab itu, tanaman harus menyerap unsur hara lebih banyak dari dalam tanah untuk melakukan pemulihan.

Tidak ada pengaruh pemangkasan terhadap ukuran panjang malai, namun pada padi Pandan Wangi, ukuran panjang malai menurun. Hal ini disebabkan malai padi yang dihasilkan kurang memperoleh makanan yang cukup dari tanaman yang dipangkas, karena makanan yang disimpan di dalam tubuh tanaman digunakan lebih dahulu untuk pertumbuhan vegetatif tanaman untuk mencapai pertumbuhan normal. Pengaruh pemupukan tidak berbeda nyata antarperlakuan terhadap panjang malai. Menurut Tan (2000), Jamilah et al. (2008), Nurhajati dan Agustian (2012), unsur hara yang diserap tanaman dalam bentuk terlarut di dalam tanah, baik melalui intersepsi akar, difusi, maupun aliran massa.

Pengaruh aplikasi pupuk dan pemangkasan terhadap umur berbunga dan berat gabah kering panen disajikan dalam Tabel 3. Pemangkasan setinggi $5 \mathrm{~cm}$ dari permukaan tanah memperlambat umur panen hingga 10 hari, dibandingkan tanaman padi yang dipangkas $15 \mathrm{~cm} \mathrm{dpt}$ yaitu hanya 6 hari. Pemangkasan yang terlalu panjang mengakibatkan pemulihan tanaman menjadi lebih lambat, sehingga menghasilkan pembungaan atau masuknya fase generatif yang lebih lambat. Hal ini berbeda dengan 
pemangkasan pada ketinggian $15 \mathrm{~cm}$ dpt yang menyebabkan keterlambatan pemulihan tanaman hanya sekitar 1 minggu saja.

Berdasarkan hasil penelitian yang diperoleh, tanaman padi hanya memiliki waktu selama $7-10$ hari untuk pulih kembali dan menghasilkan bagian generatif. Padahal untuk mencapai fase generatif, tanaman sudah mempersiapkan cadangan asimilat yang disimpan di dalam bagian batang

Tabel 1. Pengaruh pemberian pupuk kompos $C$. odorata dan pupuk buatan terhadap berat hijauan pakan ternak segar yang dipanen pada awal primordial bunga dan berat gabah kering pada padi IR66 dan Pandan Wangi.

\begin{tabular}{|c|c|c|c|c|c|c|c|c|}
\hline \multirow{3}{*}{$\begin{array}{c}\text { Pemupukan } \\
\text { kompos dan } \\
\text { pupuk buatan }\end{array}$} & \multicolumn{4}{|c|}{$\begin{array}{c}\text { Dipotong saat awal primordial bunga pada berbagai } \\
\text { ketinggian tanaman }\end{array}$} & \multicolumn{4}{|c|}{ Berat jerami saat dipanen $\left(\mathrm{Mg} \mathrm{ha}^{-1}\right)$} \\
\hline & \multicolumn{2}{|c|}{$5 \mathrm{~cm} \mathrm{dpt}$} & \multicolumn{2}{|c|}{$15 \mathrm{~cm} \mathrm{dpt}$} & \multicolumn{2}{|c|}{ IR66 } & \multicolumn{2}{|c|}{ Pandan Wangi } \\
\hline & & & $\mathbf{C} / \mathbf{N}$ & Protein $(\%)$ & $\mathbf{P}_{0}$ & $5 \mathrm{~cm} \mathrm{dpt}$ & $\mathbf{P}_{0}$ & $15 \mathrm{~cm} \mathrm{dpt}$ \\
\hline $\mathrm{F}_{1}$ & $7,34^{\mathrm{a}}$ & $7,29^{\mathrm{a}}$ & $31,60^{\mathrm{b}}$ & 8,94 & $10,87^{\mathrm{a}}$ & $6,80^{\mathrm{a}}$ & $19,17^{\mathrm{a}}$ & $10,93^{\mathrm{ab}}$ \\
\hline $\mathrm{F}_{2}$ & $5,41^{\mathrm{b}}$ & $6,73^{\mathrm{a}}$ & $29,79^{\mathrm{ab}}$ & 9,60 & $11,08^{\mathrm{a}}$ & $6,90^{\mathrm{a}}$ & $17,55^{\mathrm{b}}$ & $11,80^{\mathrm{a}}$ \\
\hline $\mathrm{F}_{3}$ & $6,54^{\mathrm{ab}}$ & $7,49^{\mathrm{a}}$ & $26,55^{\mathrm{a}}$ & 10,94 & $11,04^{\mathrm{a}}$ & $6,20^{\mathrm{a}}$ & $17,42^{\mathrm{b}}$ & $8,50^{\mathrm{b}}$ \\
\hline Rataan & $6,43^{\mathrm{A}}$ & $7,17^{\mathrm{A}}$ & & & $10,99^{\mathrm{B}}$ & $6,33^{\mathrm{C}}$ & $18,05^{\mathrm{A}}$ & $10,41^{\mathrm{B}}$ \\
\hline
\end{tabular}

Keterangan: Angka yang diikuti dengan huruf kecil yang sama pada kolom yang sama dan angka yang diikuti dengan huruf besar yang sama pada baris yang sama tidak berbeda nyata menurut uji BNT pada taraf $\alpha=5 \%$. Nilai C/N (karbon/nitrogen), $\mathrm{P}_{0}$ (tidak dipangkas), $\mathrm{F}_{1}\left(5 \mathrm{Mg} \mathrm{ha}^{-1}\right.$ kompos $C$. odorata $+100 \%$ pupuk buatan rekomendasi (PBR), $\mathrm{F}_{2}\left(7,5 \mathrm{Mg} \mathrm{ha}^{-1}\right.$ kompos $C$. odorata $\left.+75 \% \mathrm{PBR}\right)$, dan $\mathrm{F}_{3}(5$ $\mathrm{Mg} \mathrm{ha}^{-1}$ kompos C. odorata $+50 \%$ PBR).

Tabel 2. Pengaruh pemangkasan dan pemupukan terhadap jumlah anakan produktif dan panjang malai.

\begin{tabular}{|c|c|c|c|c|c|c|c|c|}
\hline \multirow{2}{*}{$\begin{array}{c}\text { Perlakuan } \\
\text { pemupukan }\end{array}$} & \multicolumn{4}{|c|}{ Anakan produktif } & \multicolumn{4}{|c|}{ Panjang malai padi (cm) } \\
\hline & $\mathbf{P}_{0}$ & $5 \mathrm{~cm} \mathrm{dpt}$ & $\mathbf{P}_{0}$ & $15 \mathrm{~cm} \mathrm{dpt}$ & $\mathbf{P}_{0}$ & $5 \mathrm{~cm} \mathrm{dpt}$ & $\mathbf{P}_{0}$ & $15 \mathrm{~cm} \mathrm{dpt}$ \\
\hline $\mathrm{F}_{1}$ & $23,00^{\mathrm{a}}$ & $19,33^{\mathrm{a}}$ & $20,67^{\mathrm{a}}$ & $18,89^{\mathrm{a}}$ & $23,16^{\mathrm{a}}$ & $21,47^{\mathrm{a}}$ & $27,95^{\mathrm{a}}$ & $23,99^{\mathrm{ab}}$ \\
\hline $\mathrm{F}_{2}$ & $20,50^{\mathrm{a}}$ & $18,00^{\mathrm{a}}$ & $20,66^{\mathrm{a}}$ & $18,44^{\mathrm{a}}$ & $20,02^{\mathrm{a}}$ & $20,07^{\mathrm{a}}$ & $26,30^{\mathrm{a}}$ & $24,53^{\mathrm{a}}$ \\
\hline $\mathrm{F}_{3}$ & $19,00^{\mathrm{a}}$ & $18,50^{\mathrm{a}}$ & $25,44^{\mathrm{a}}$ & $20,55^{\mathrm{a}}$ & $22,01^{\mathrm{a}}$ & $21,73^{\mathrm{a}}$ & $25,87^{\mathrm{a}}$ & $21,40^{\mathrm{b}}$ \\
\hline Rerata & $20,83^{\mathrm{A}}$ & $18,61^{\mathrm{B}}$ & $22,26^{\mathrm{A}}$ & $19,30^{\mathrm{AB}}$ & $21,72^{\mathrm{B}}$ & $21,08^{\mathrm{B}}$ & $26,71^{\mathrm{A}}$ & $23,31^{\mathrm{AB}}$ \\
\hline
\end{tabular}

Keterangan: Angka yang diikuti dengan huruf kecil yang sama pada kolom yang sama dan angka yang diikuti dengan huruf besar yang sama pada baris yang sama pada masing-masing parameter tidak berbeda nyata menurut uji BNT pada taraf $\alpha=5 \%$.

Tabel 3. Pengaruh aplikasi pupuk organik dan pupuk buatan serta perlakuan pemangkasan terhadap umur berbunga dan berat gabah kering panen pada padi IR66 dan Pandan Wangi.

\begin{tabular}{|c|c|c|c|c|c|c|c|c|}
\hline \multirow{3}{*}{$\begin{array}{c}\text { Perlakuan } \\
\text { pemupukan }\end{array}$} & \multicolumn{4}{|c|}{ Umur berbunga (hst) } & \multicolumn{4}{|c|}{ Berat gabah kering panen $\mathrm{Mg} \mathrm{ha}^{-1}$} \\
\hline & \multicolumn{2}{|c|}{ IR66 } & \multicolumn{2}{|c|}{ Pandan Wangi } & \multicolumn{2}{|c|}{ IR66 } & \multicolumn{2}{|c|}{ Pandan Wangi } \\
\hline & $\mathbf{P}_{\mathbf{0}}$ & $5 \mathrm{~cm} \mathrm{dpt}$ & $\mathbf{P}_{0}$ & $15 \mathrm{~cm} \mathrm{dpt}$ & $\mathbf{P}_{\mathbf{0}}$ & $5 \mathrm{~cm} \mathrm{dpt}$ & $\mathbf{P}_{\mathbf{0}}$ & $15 \mathrm{~cm} \mathrm{dpt}$ \\
\hline$\overline{F_{1}}$ & 59,66 & 69,66 & 52,00 & 56,67 & $5,43^{\mathrm{a}}$ & $4,27^{\mathrm{a}}$ & $6,95^{\mathrm{a}}$ & $4,17^{\mathrm{a}}$ \\
\hline $\mathrm{F}_{2}$ & 58,33 & 67,33 & 50,33 & 56,67 & $5,54^{\mathrm{a}}$ & $4,89^{\mathrm{a}}$ & $5,75^{\mathrm{b}}$ & $4,17^{\mathrm{a}}$ \\
\hline $\mathrm{F}_{3}$ & 59,66 & 69,66 & 50,67 & 56,00 & $5,50^{\mathrm{a}}$ & $3,36^{\mathrm{b}}$ & $6,00^{\mathrm{ab}}$ & $4,30^{\mathrm{a}}$ \\
\hline Rerata & 59,22 & 68,88 & 51,00 & 56,67 & $5,49^{\mathrm{AB}}$ & $4,17^{\mathrm{B}}$ & $6,22^{\mathrm{A}}$ & $4,20^{\mathrm{B}}$ \\
\hline
\end{tabular}

Keterangan: Angka yang diikuti dengan huruf kecil yang sama pada kolom yang sama dan angka yang diikuti dengan huruf besar yang sama pada baris yang sama berbeda tidak nyata menurut uji BNT pada taraf $\alpha=5 \%$. P0 $=$ tidak dipangkas.

Pada tanaman padi yang dipangkas, secara umum gabah yang dihasilkan menurun sekitar 1-2 $\mathrm{Mg} \mathrm{ha}^{-1}$. Hasil ini cukup signifikan jika dibandingkan dengan tanaman yang tidak dipangkas. Penurunan hasil padi disebabkan makanan yang disiapkan untuk menghasilkan benih, diangkut bersama hijauan yang dipangkas saat fase sebelum primordial bunga. Hal ini menunjukkan bahwa tanaman padi yang dipangkas, semua bagian vegetatifnya masih mampu memproduksi gabah. Kemampuan tanaman untuk menghasilkan bunga, malai, dan gabah juga tidak terganggu akibat pemangkasan.
Perlakuan pemangkasan pada tanaman padi, selain membantu peternak dalam menyediakan hijauan pakan ternak, juga menyediakan gabah padi sebagai bahan pangan bagi masyarakat. Di samping itu, adanya pemangkasan juga mendorong tanaman padi untuk memaksimalkan penyerapan hara dari dalam tanah, sehingga efisiensi pemupukan menjadi meningkat. Oleh karena tanaman padi masih mampu menghasilkan gabah meskipun mengalami penurunan akibat pemangkasan, diperlukan suatu upaya tertentu agar produksi padi melebihi tanaman yang tidak dipangkas, sehingga produksi gabah kering meningkat. 
Berat gabah kering panen tertinggi diperoleh pada tanaman yang tidak dipangkas. Berat gabah kering panen terendah dihasilkan pada tanaman padi yang dipangkas pada ketinggian $5 \mathrm{~cm}$ dpt dan tidak berbeda nyata dengan tanaman yang dipangkas pada ketinggian $15 \mathrm{~cm}$ dpt. Pada tanaman yang tidak dipangkas, hasil gabah kering panen (GKP) secara umum lebih tinggi jika dibandingkan dengan tanaman yang dipangkas. Jamilah et al. (2015a; 2015b) menjelaskan bahwa produksi padi pada tanaman yang tidak dipangkas lebih tinggi dibandingkan dengan tanaman yang dipangkas. Hal ini disebabkan asimilat yang dihasilkan pada tanaman padi secara maksimal disimpan dalam bulir padi yang berupa gabah serta adanya pemberian pupuk yang cukup pada tanaman. Jamilah et al. (2008; 2014a; 2014b) membuktikan bahwa apabila tanaman memperoleh makanan (unsur hara) yang cukup, tanaman akan tumbuh optimal, baik sumber unsur hara berasal dari bahan organik maupun anorganik. Menurut Tan (2000), tanaman menyerap unsur hara dalam bentuk mineral anorganik. Oleh sebab itu, jika pupuk yang diberikan berupa bahan organik, bahan organik akan mengalami mineralisasi lebih dahulu agar unsur hara dapat diserap tanaman dalam bentuk ion, baik berupa ion positif maupun ion negatif.

\section{SIMPULAN}

Hijauan pakan ternak tertinggi diperoleh dari perlakuan pemangkasan tanaman pada awal primordial bunga pada ketinggian $15 \mathrm{~cm}$ dari permukaan tanah mencapai 7,17 Mg $\mathrm{ha}^{-1}$. Pada perlakuan pemangkasan, berat gabah padi kering giling tertinggi pada tanaman yang dipangkas $15 \mathrm{~cm}$ dari permukaan tanah, yaitu mencapai 4,20 $\mathrm{Mg} \mathrm{ha}^{-1}$. Secara umum, pemberian $5 \mathrm{Mg} \mathrm{ha}^{-1}$ pupuk kompos C. odorata + $100 \%$ pupuk buatan rekomendasi merupakan komposisi pupuk yang paling tepat untuk menghasilkan gabah padi dan hijauan pakan ternak.

\section{UCAPAN TERIMA KASIH}

Ucapan terima kasih disampaikan kepada para mahasiswa yang telah bersama-sama melakukan penanaman dan pemeliharaan tanaman, selanjutnya kepada Kementerian Riset dan Teknologi Pendidikan Tinggi, atas dibiayainya penelitian ini melalui kegiatan Hibah Strategis Nasional Tahun 1, dengan DIPA Dirjen Dikti Tahun 2015,
No. SP-DIPA-023.04.1.673453/2015, Tanggal 14 November 2014, dengan surat penugasan No. 10/KONTRAK/010/KM/2015, Tanggal 16 Februari 2015.

\section{DAFTAR PUSTAKA}

Atman, Chairuman N, Dahono. 2012. Uji adaptasi varietas unggul baru padi sawah berbasis pendekatan pengelolaan tanaman terpadu di Sumatera Barat. Prosiding Seminar Nasional Inovasi Pertanian Spesifik Lokasi, Percepatan, dan Perluasan Inovasi Pertanian Spesifik Lokasi Mendukung Empat Sukses Pembangunan Pertanian. Balai Besar Pengkajian dan Pengembangan Teknologi Pertanian, Kementerian Pertanian, Medan, 6-7 Juni 2012.

BPS [Badan Pusat Statistik]. 2016. Sumatera Barat dalam Angka tahun 2015. Badan Pusat Statistik, Jakarta.

BPTP Sulawesi Tengah. 2009. Kajian peningkatan intensitas tanaman padi sawah di Sulawesi Tengah (APBN). http://sulteng.litbang.pertanian.go.id/ [18 April 2016].

Dinas Peternakan Jawa Barat. 2016. Hijauan Pakan Ternak (HMT). http://disnak.jabarprov.go.id/ [10 Mei 2016].

Hakim N, Agustian. 2012. Titonia untuk pertanian berkelanjutan. Andalas University Press, Padang.

Jamilah, Ediwirman, Ernita M. 2013. Peranan gulma Chromolaena odorata dan sabut kelapa sebagai bahan baku POC untuk menggantikan $\mathrm{K}$ untuk pertumbuhan dan hasil padi ladang. Prosiding Seminar Nasional Pengembangan Agroindustri untuk Mendukung Perekonomian Rakyat. Politeknik Pertanian, Payakumbuh, 29 November 2013.

Jamilah, Ediwirman, Ernita M. 2015a. The effect of fermented liquid fertilizer and potassium for nutrient uptake and yield of rice at tropical upland. Journal of Environmetal Research and Development 9(4): 1060-1065.

Jamilah, Fatimah, Munir R. 2011. Pengayaan pupuk bioorganik Chromolaena odorata dengan tepung tulang dan PF lokal untuk meningkatkan $20 \%$ hasil padi aromatik PTS multilokasi. Laporan Penelitian kerjasama antara KKP3T Badan Litbang Jakarta dan Universitas Tamansiswa, Padang.

Jamilah, Juniarti, Mulyani S. 2015b. Potensi tanaman padi dipangkas secara periodik untuk pakan ternak metode budi daya integrasi padi ternak menunjang kedaulatan pangan dan daging. Laporan Penelitian Stranas Tahun 1. Universitas Tamansiswa, Padang.

Jamilah, Paramida C, Ernita M. 2014. Penetapan konsentrasi dan interval pemberian POC dan Tithonia diversifolia untuk meningkatkan hasil padi ladang. Prosiding Seminar Nasional Pembangunan Bioindustri untuk Mewujudkan Kedaulatan Pangan Indonesia. Politeknik Pertanian, Payakumbuh, 3-4 September 2014.

Jamilah, Yohanes, Widodo H. 2008. Efek residu kompos Chromolaena odorata dan Guano upaya menghemat pupuk buatan untuk tanaman bawang pada tanah marginal. Jurnal Embrio 1(2): 63-73.

Kuspriyantono T. 2008. Korelasi Jenis dan Dosis Pupuk dengan Produktivitas Padi (Oryza sativa L.) di Kecamatan Jatisrono, Kabupaten Wonogiri. [Skripsi]. Universitas Sebelas Maret, Surakarta

Martawidjaja M. 2003. Pemanfaatan jerami padi sebagai pengganti rumput untuk ternak ruminansia kecil. Wartazoa 13(3).

PNPM Agribisnis Perdesaan. 2009. Hijauan pakan ternak: Rumput gajah https://nusataniterpadu.wordpress.com/ [11 April 2016].

Sinar Tani. 2013. Pengembangan dan pengelolaan pakan ternak. http://m.tabloidsinartani.com/ [11 April 2016].

Singa P. 2013. HMT (Hijauan Makanan Ternak). Peternakan. http://kesehatanternak.blogspot.co.id/ [11 April 2016]

Suprihatno, Bambang, Aan A et al. 2009. Deskripsi varietas padi. Balai Besar Penelitian Tanaman Padi, Badan Penelitian dan Pengembangan Pertanian, Departemen Pertanian.

Susanti S. 2007. Produksi dan kecernaan in vitro rumput gajah pada berbagai imbangan pupuk nitrogen dan sulfur. Buana Sains 7(2): 151-156.

Tan KH. 2000. Environmental soil science. Second Edition. Marcell Dekker, USA. 